TEME, г. XLIV, бр. 3, јул - септембар 2020, стр. 1081-1099

Оригинални научни рад https://doi.org/10.22190/TEME181119067I

Примљено: 19. 11. 2018.

UDK 347.79(47)

Ревидирана верзија: 20. 9. 2020.

Одобрено за штампу: 1. 10. 2020.

\title{
ЕВОЛУТИВНИ РАЗВОЈ БРОДАРЕВЕ ОДГОВОРНОСТИ У РИМСКОМ ПРАВУ ${ }^{a}$
}

\author{
Марија Игњатовић \\ Универзитет у Нишу, Правни факултет, Ниш, Србија \\ marija@prafak.ni.ac.rs
}

\begin{abstract}
Апстракт
О одговорности бродара у римском праву почиње да се говори са развојем поморске трговине и правне регулативе која је пратила овај развој. До развоја пловидбе код Римљана дошло је у периоду након освајање Картагине (146. г. пре н. е.) и тај је развој трајао све до доношења Јустинијанове компилације (527. г. н. е.). У овом дугом периоду питање одговорности бродара није увек имало једнак правни третман. Наиме, имајући у виду све друштвено-економске околности у којима се развијала поморска пловидба, одговорност бродара била је утемељена на различитим правним принципима. Тако, у периоду позне републике, она је представљала одступање од начела alteri stipulari nemo potest, у класичном периоду била је заснована на искључивој voluntas бродара, која се огледала у именовању капетана брода, док је у посткласичном периоду развоја римског права ова врста одговорности била утемељена на принципима сигурности и заштите интереса путника и робе у поморском превозу, што је разумљиво имајући у виду прилике у друштву овог доба (несигурност пловидбе на мору због поновне појаве пирата). Из тог разлога, у раду ће се ово питање посматрати кроз одговарајуће временске оквире (период позне републике, класично и посткласично право), ради лакшег праћења и разумевања законитости у вези са настанком и развојем института бродареве одговорности.
\end{abstract}

Кључне речи: еволуција бродареве одговорности, alteri stipulari nemo potest, voluntas, принцип сигурности и заштите интереса путника.

\footnotetext{
${ }^{a}$ Рад је резултат истраживања на пројекту „Усклађивање права Србије са правом Европске уније”, који финансира Правни факултет Универзитета у Нишу у периоду од 2013. до 2018.
} 


\title{
EVOLUTIONAL DEVELOPMENT OF THE SHIPPER'S LIABILITY IN ROMAN LAW
}

\begin{abstract}
The liability of the shipper in Roman law begins to be discussed with the development of maritime trade and following legal regulations. The development of navigation with the Romans came after the conquest of Carthage (146 BC), and this development lasted until the passing of Justinian's compilation (527 BC). In this long period of time, the issue of the shipper's liability did not always have the same legal treatment. Namely, bearing in mind all the social and economic circumstances in which maritime navigation has developed, the shipper's liability was based on different legal principles. Thus, during the late republic, it represented a deviation from the principle of alteri stipulari nemo potest; in the classical period, it was based on the exclusive voluntas of the shipper, which was reflected in the appointment of the captain of the ship, while in the post-classical period of the development of the Roman law, this type of responsibility was based on the principles of safety and protection of the interests of passengers and goods in maritime transport, which is understandable given the social circumstances of this period (uncertainty of navigation by sea due to the recurrence of pirates). For this reason, this issue will be addressed through appropriate time frames (the late republican period, classical and post-classical law), so the creation and development of the institute of the shipper's liability would be easy to monitor and understand.
\end{abstract}

Key words: evolution of shipper's liability, alteri stipulari nemo potest, voluntas, the principles of safety and protection of passenger's interests.

\section{УВОД}

О одговорности бродара у римском праву први пут почиње да се говори са развојем поморске трговине. До њеног развоја дошло је у оном периоду римске државе када је Рим постао јака и територијално велика држава, услед учесталих ратовања и све развијеније трговине (након пунских ратова) (Ignjatović, 2018:120). То је био период географског ширења римске државе од мале монолитне заједнице до државе у правом смислу те речи, која је, географски посматрано, обухватала читаво Апенинско полуострво (на коме је живело хетерогено становништво), а након победе над Картагином и цео Медитеран (Ignjatović, 2017:186).

Преко Медитерана свет је био повезан као никад до тада. Римске лађе пловиле су свуда по Медитерану, по Црном и Црвеном моpy, све до Индије, на западу дуж обале данашњег Марока, а на северозападу све до Британије. Путовало се углавном дању, мада нису били ретки случајеви да се превоз обављао и ноћу помоћу звезда. Као мера предострожности, пловидба је била ограничена на осам месеци у току једне године, искључујући зиму, од пролећа до јесени. 
Уз повољан ветар дневно се прелазило од 70 до 90 миља. ${ }^{1}$ Лука Рима била је Остиа на ушћу реке Тибра, а Брундисиум, данашњи Бриндиси, била је лука одакле су бродови кретали у Грчку и даље на исток. Познате луке у Грчкој биле су грчки градови Пиреј (у Атици) и Ефес (у Малој Азији), острва Делос, Родос и Кипар. Највећа лука на Медитерану била је Александрија у Египту, одакле су се према Риму кретали велики теретни бродови натоварени житом.

Окупација околних народа након пунских ратова, потискивање пирата са мора и коришћење војних путева искључиво у трговачке сврхе (Stojčević, 1947: 47), омогућили су додир са различитим културама, различитим добрима, што је нарочито погодовало свеопштем развоју трговине (Stojčević, 1947: 47). ${ }^{2}$ Већина предмета производила се за потребе локалног становништва, али постојале су и одређене регије Царства које су биле специјализоване само за одређене производе, због којих су трговци знали да путују веома далеко, некад и ван граница Царства.

Са процватом поморске трговине, јавила се и потреба за постојањем правне регулативе, помоћу које би се решавали проблеми који су се појављивали паралелно са њеним развојем. Иако су Римљани правној науци били познати по правничкој домишљатости, правничкој логици, тумачењу права и стварању права у складу са потребама праксе (Ignjatović, 2016: 325-338), мало је вероватно да су они били први творци правних правила поморске трговине, будући да они нису историји познати као поморски народ, већ је то, много пре њих, био хеленски народ, чије је поморско право било развијено већ у IX веку пре нове ере (lex Rhodia de iactu) (Ignjatović, 2017: 186). ${ }^{3}$ Међутим, захваљујући рецепцији поморског права са острва Родос, до које је дошло након покоравања овог острва, Римљани су спремно дочекали развој поморске трговине. Постојање полазишта поморског права пружило им је могућност да даље развијају ову област права, посебно у делу везаном за транспортну индустрију. Тако

\footnotetext{
${ }^{1}$ Од Родоса до Александрије, на пример, путовало се три дана, а од Брундизија до Крфа девет сати.

${ }^{2}$ Паралелно се развијају и друга два помагача трговине: новац и кредит.

${ }^{3}$ Ово законодавсто се развијало под јаким утицајем Феничана. Утицај Феничана, најзначајнијих трговаца античког доба, било је изражено на Родосу, будући да је Родос дуго био њихова колонија. Родски поморски законик (lex Rhodia de iactu) никада није физички нађен, али, према делима римских историчара, датира из 475-479. године пре нове ере. Уколико је било неопходно да се део робе која се превози бродом баци у море како би се брод олакшао, капетан брода је ослобађан одговорности, а такво жртвовање робе сносили би сви учесници у заједничком подухвату. Дакле, било је речи о сношењу ризика од стране свих учесника у поморској трговини. Ово законодавство касније је било инкорпорирано у римско, а отуда и у византијско законодавство.
} 
да се римско поморско право није задовољило само усвојеним одредбама о заједничкој хаварији, о сношењу и подели ризика услед незгода насталих у току превоза робе морем, о поморском зајму (foenus nauticum $),{ }^{4}$ већ и кроз увођење нових института, пре свега у форми уговора о превозу робе морем (locatio conductio operis faciendi), као и кроз стварање нових процедуралних средстава којима је била утврђена одговорност даваоца услуга, као и заштита интереса корисника услуга поморског подухвата (путника).

На темељу анализе релевантних правних извора, у раду ће се на основу горе датих ширих објашњења обрадити питање еволутивног развоја бродареве одговорности, и то тако што ће се овом питању посветити посебна пажња, односно тако што ће се посматрање бродареве одговорности вршити у тачно одређеним временским оквирима, у периоду позне републике, класичном и посткласичном периоду.

\section{БРОДАРЕВА ОДГОВОРНОСТ \\ У ПЕРИОДУ ПОЗНЕ РЕПУБЛИКЕ}

Период позне републике, иако временски посматрано релативно кратак (век и по), био је врло значајан и занимљив период у развоју римске државе, посебно са економског и правног аспекта. То је био период када су Римљани након освајања Картагине завладали Медитераном и када су освојили северну и јужну Галију. У новоосвојеним земљама основали су своје колоније (провинције) и изградили су саобраћајне везе за несметани развој трговине (Ignjatović, 2002:328). ${ }^{5}$ У оваквим околностима цео базен Средоземног мора, скоро читав антички свет, постао је једно велико трговачко подручје (Stojčević, 1947: 47).

У првим данима развоја поморске трговине, поморски превоз обављао је сам патерфамилијас бродар (exercitor navis). То је био период када су још увек функције власника (бродара) и заповедника брода биле обједињене у исту личност, пре свега из разлога еконо-

\footnotetext{
${ }^{4}$ Потребу за постојањем поморског зајма Демостен је оправдавао речима: „трговина не потиче од оних који узимају, већ од оних који позајмљују, без којих транспортни брод, нити морнар, нити путник не би могао да оде".

${ }^{5}$ Неки од покорених народа у овом периоду били су на далеко вишем културном нивоу од Римљана. То је нарочито био случај са Етрурцима. Они су већ познавали развијене робовласничке односе и високу техничку културу, нарочито у обради метала... Грци, који су настањивали градове на југу Полуострва, били су мајстори прекоморске трговине. У Кампањи су били врло развијени занати... Покоравајући ове народе, Римљани нису уништили њихове културе. Оне су само биле заустављене у њиховом развитку, а затим укључене у римску ратну и државну машину. То је у огромној мери подигло производне снаге Римљана и њихов општи културни ниво.
} 
мичности (Šarac, 2008: 85). ${ }^{6}$ Са друге стране, у овом периоду доминантну улогу и даље је имало начело alteri stipulari nemo potest, што је значило да је само патерфамилијас био тај који је могао самостално у своје име и за свој рачун да закључује правне послове, тј. да организује пловидбени подухват и да сноси све користи и штете од давања брода.

Међутим, са даљим развојем правно-економског промета, посебно пред крај периода републике, ситуација се битно променила. Новонасталим приликама одговарала је појава приватне својине, њено нагомилавање, као и увођење traditio као неформалног начина за стицање својине, који је омогућавао брз промет, стицањем својине $a$ manu in тапи. Ослобађање трговине од строгог формализма, који је до тада био присутан кроз форму mancipatio, условио је потребу за сужавањем обима правне способности pater familias, а у корист лица alieni iuris и робова. Заправо, потреба патерфамилијаса да закључује велики број правних послова у исто време са различитим уговорним странама и на различитим местима - условила је потребу сужавања обима његове правне способности, а у корист ових лица.

Сужавање обима правне способности патерфамилијаса у корист лица која су живела по његовом праву довело је до тога да су лица alieni iuris, па чак и робови, могли да иступају у правно-економском промету и да по његовом налогу закључују одређене правне послове, иако је преовладавало схватање, нарочито код Римљана из виших друштвених слојева, да је директно учествовање лица alieni iuris и робова у тим пословима испод њиховог достојанства. Међутим, и поред преовлађујућег схватања, старешине породица радо су делиле профите од овако закључених правних послова тако што су они били власници ових робова, а одредбе старог римског права су предвиђале такву могућност.

Gai.Inst. 2.86: ADQUIRITUR AUTEM NOBIS NON SOLUM PER NOSMET IPSOS, SED ETISM PER EOS QUOS IN POTESTATE MANU MANCIPIOVE HABEMUS; ITEM PER EOS SERVOS, IN QUIBUS USUM FRUCTUM HABEUS; ITEM PER HOMINES LIBEROS ET SERVOS ALIENOS QUOS BONA FIDE POSSIDEMUS. DE QUIBUS SINGULIS DILIGENTER DISPICIAMUS. (Gai, превод Станојевић, 2009: $122-123)^{7}$

У том случају, pater familias се сматрао власником који је убирао плодове са својих ствари.

\footnotetext{
6 У време неразвијеног поморства, власник брода лично је пратио брод и склапао је послове везане за његово пословање, управљање и одржавање.

7 „Себи прибављамо не само сопственим радњама већ и преко других лица, лица alieni iuris и робова, било да су они то стекли, уговором или наследством.”
} 
Међутим, учешће лица alieni iuris и робова у правно-економском промету довело је и до одређене правне несигурности, јер нико није хтео да се са тим лицима упушта у пословање, нити да склапа правне послове, јер нису имала сопствену имовину, а господара нису могли на овај начин да обавезују. Осим тога, велику сметњу укључивању тих особа у правни промет представљало је римско схватање да уговори обавезују само оне који учествују у њиховом склапању (alteri stipulari nemo potest). Ако би било таквих који су склопили неки правни посао са овим лицима, нису ни на који начин могли да наплате своје потраживање (Šarac, 2011:45) jep је било речи о природним облигацијама (obligationes naturalles), неутуживим, али наплативим.

Новонастала ситуација захтевала је додатну активност претоpa, у смислу проналажења нових еластичнијих решења, која би представљала одступање од строгог начела alteri stipulari nemo potest, које је све више кочило потребу за брзим правно-економским развојем. Решење је пронађено залагањем претора и увођењем шест нових тужби (actiones adiecticiae qualitatis) у Едикт (Bujuklić, 2013: 142) Увођењем нових тужби био је проширен обим одговорности pater familias тако што је он могао да одговара и за штету причињену туђим радњама.

Другим речима, претор је омогућио лицима alieni iuris и робовима да склапају правне послове, и то тачно у одређеним ситуацијама, које је наводио у Едикту и за које је предвиђао правну заштиту трећим лицима, путем одређених тужби (Šarac, 2011: 46). ${ }^{9}$ На овај начин био је направљен изузетак од правила inter partes, одступило се од начела alteri stipulari nemo potest и била је проширена уговорна одговорност патерфамилијаса (ноксална одговорност) (Grupс̌е, 1962: 166). ${ }^{10}$

${ }^{8}$ Од лат. adiecticius - додат, назив који су средњовековни правници (глосатори) дали јер су обавезе које су оне производиле биле „придодате” основној одговорности патерфамилијаса.

${ }^{9}$ То је чињено на тај начин што је претор у већ постојећој тужби само мењао имена субјекта тако што је у интенцији формуле наводио име лица alieniiuris или роба, који су закључили правни посао, док је кондемнација и даље била уперена против патерфамилијаса.

10 Увођење ноксалне одговорности, где породични старешина деликтно одговара за штету коју су причинили његови укућани, била је последица општеприхваћеног принципа да је било нужно да се надокнади свака причињена штета. Међутим, примена овог принципа по правилу се односила на оно лице које је причинило штету, али код ноксалне одговорности имамо ситуацију која представља изузетак од овог правила. Било је речи о одговорности која је у великој мери слична са савременом одговорности родитеља за штету коју причине њихова деца, али се од ње разликује јер је била заснована на сасвим другачијим принципима. Римљани су ноксалну одговорност строго везивали за личност, тако је ноксално био одговоран сваки патерфамилијас у чију би породицу прешло лице које је причинило штету. 
Једна од тих тужби била је и actio exercitoria, која се односила на оне случајеве када је патерфамилијас бродар (exercitor navis) именовао лице alieni iuris или роба за капетана брода. У том случају претор је допуштао подизање тужбе не само против капетана брода (лица alieni iuris или роба) већ и против бродара (exercitor navis), који је у том случају одговарао за цео износ (in solidum).

P.S. 2.6.1: FILIUS FAMILIAS SI VOLUNTATE PATRIS NAUEM EXERCEAT, PARTEM IN SOLIDUM OB EA, QUAE SALUA RECEPERIT, OBLIGAT. (Paulo, превод Ромац, 1989: 81) ${ }^{11}$

Да би подизање тужбе било изводљиво, једино је било битно да је у правном акту постављења (praepostitio), недвосмислено била изражена воља (voluntas) бродара (exercitor) да за капетана брода именује лице alieni iuris или роба. Из овога произлази да је акт постављења био темељна претпоставка за претора за допуштање тужбе против бродара (Šarac, Miletić, 2017: 421-431).

Дакле, са развојем поморске трговине у периоду позне републике и са увођењем traditio, који је омогућавао брз промет, стицањем својине a тапи іп тапи, дошло је до одређених промена у привредној структури римске државе, које су неминовно наметале потребу за ослобађањем од строгог формализма, до тада присутног у сфери својинских односа. Ослобађању од строге форме погодовало је и увођење actiones adiectitiae qualitatis, које су на известан начин представљале одступање од начела alteri stipulari nemo potest, у циљу постизања веће ефикасности у правно-економском промету. То је посматрано са аспекта бродареве одговорности и довело је до ширења обима ове одговорности и на оне случајеве када је до одговорности долазило на основу послова које су по налогу патерфамилијаса закључила лица alieni iuris и робови. То је даље значило да је voluntas, односно воља, бродара постала темељ његове даље одговорности и да је, као битан елемент на коме је почивала одговорност бродара у класичном периоду, била у духу utilitas navigantium и necessitas contrahendi.

D. 14.1.1.4 (Ulp. 28 ad ed.): CUIUS AUTEM CONDICIONIS SIT MAGISTER ISTE, NIHIL INTEREST, UTRUM LIBER AN SERVUS, ET UTRUM EXERCITORIS AN ALIENUS: SED NEC CUIUS AETATIS SIT, INTERERIT, SIBI IMPUTATURO QUI PRAEPOSUIT. ${ }^{12}$

\footnotetext{
11 „Ако син породице (подређена особа) управља бродом по вољи оца, отац одговара за све што је преузето на чување (превоз).”

${ }^{12}$ D. 14.1.1.4 (Ulp. 28 aded.) Лично-правни статус капетана је без значења; није важно је ли слободан или роб, и да ли је бродарев роб или неко друго лице. Нити је важна његова старост, јер о томе мора да води рачуна онај ко га је својом вољом поставио.
} 


\section{БРОДАРЕВА ОДГОВОРНОСТ У КЛАСИЧНОМ ПЕРИОДУ}

Увођењем actio exercitoria у поморско-правне односе у II в. пре н. е. не само да је дошло до бржег промета у поморској трговини већ и до давања примата вољи бродара (voluntas), што је било у духу класичног периода. Консенсуализам, већ присутан с краја периода републике, у класичном периоду се огледао у voluntas exercitor-a да именује капетана брода, што је директно утицало на обим praepositio, а самим тим и на обим бродареве одговорности.

Класични период остао је у историји Рима упамћен као период свеопштег просперитета. У трговачком погледу, био је то период велике експанзије на исток. „Римски трговци су експлоатисали не само Малу Азију већ су прешли Суецки земљоуз и продрли чак до Кине. Подигнуте су велике трговачке метрополе[,] а Александрија постаје највећа пијаца старог века. У Риму се тада води луксузан живот који гута велике количине луксузних тканина, мириса и украса који се довозе са истока. У самој Италији и на западу развија се индустрија луксузне металургије и керамике и градња луксузних бродова" (Stojčević, 1947: 47). Свеопшти развој трговине зато није дозвољавао постојање крутих решења и строге форме. Потреба за брзим и ефикасним начинима за закључивање правних послова није остављала простора капетановим сауговарачима да се посебно распитују о њему или његовим квалитетима. Требало је брзо деловати, те је из тог разлога, а руководећи се начелом правичности, у класичном периоду била, пооштрена одговорност бродара за лица које је именовао за капетана брода.

Најчешће је exercitor за капетана брода (magister navis) именовао неког од својих лица alieni iuris или робове (Romac, 1994: 835), ${ }^{13}$ мада је римско право познавало да је, осим ових лица, за капетана брода могло бити постављено и слободно лице (закупац брода), које је за свој рачун професионално обављало поморски транспорт и које је одговарало трећим особама за обавезе из бродског пословања (Pezelj, 2017: 315).

Gai, Inst.4.71: EADEM RATIONE CONPARAVIT DUAS ALIAS ACTIONES, EXERCITORIAM ET INSISTORIAM. TUNC AUTEM EXERCITORIA LOCUM HABET, CUM PATER DOMINUSVE FILIUM SERVUMVE MAGISTRUM NAVI PRAEPOSUERIT, ET QUID CUM EO EIUS REI GRATIA CUI PRAEPOSITUS FUERIT GESTUM ERIT. CUM ENIM EA QUOQUE RES EX VOLUNTATE PATRIS DOMINIVE CONTRAHI VIDEATUR, AEQUISSIMUM ESSE VISUM EST IN SOLIDUM ACTIONEM IN EUM DARI. QUIN ETIAM, LICET EXTRANEUM QUISQUAE MAGISTRUM NAVI PRAEPOSUERIT SIVE SERVUM SIVE LIBERUM, TAMEN EA

\footnotetext{
13 С обзиром на чињеницу да у почетним стадијумима развоја поморске трговине Римљани нису имали превеликог искуства, најчешће су за обављање поморских послова ангажовали робове грчког или оријенталног порекла.
} 
PRAETORIA ACTIO IN EUM REDDITUR. (Gai, превод Станојевић, 2009: $318-319){ }^{14}$

Иако је римско право, посебно након увођења actio exercitoria, предвиђало могућност да, поред лица alieni iuris, за капетана брода буде именован и роб, у пракси се то ретко дешавало. Наиме, ризик који би настао у оваквој ситуацији исувише је био велики, јер је могло да се догоди да роб побегне због непостојања могућности за надзор роба (Šarac, 2008: 93). У том случају, exercitor navis био је изложен великом губитку имајући у виду колика је била вредност брода, бродске опреме, посаде и терета. Из тог разлога, у пракси се најчешће дешавало да се за капетана брода (magister navis) именовало или лице alieni iuris или слободан грађанин, коме је била поверавана брига о целом броду, док је сва одговорност била на бродару и била је процењена in solidum.

D.14.1.1.1. (Ulp. 28 ad ed): MAGISTRUM NAVIS ACCIPERE DEBEMUS, CUI TOTIUS NAVIS CURA MANDATA EST. (Šarac, 2008: 94) $)^{15}$

Полазећи од схватања кривице као субјективног односа штетника према извршеној радњи, у римском праву је, као општи принцип, преовладавало схватање да нико није био дужан да одговара за штету која је настала туђом радњом. Међутим, и од овог правила постојао је изузетак, а то је управо био случај actiones adiectitiae qualitatis, када је pater familias био у обавези да испуни обавезе или да надокнади штету коју су причинили његови укућани (ноксална одговорност).

То даље значи да, у случају да је било који правни посао био закључен између лица именованих од стране pater familias у конкретном случају exercitor-a и да је дошло до повреде уговора, друга уговорна страна могла је позвати на одговорност како лице са којим је закључила уговор (на основу тужбе из уговора) тако и самог pater familias-a (exercitora), и то на основу тужбе actio exercitoria (Šarac, 2008: 86). ${ }^{16}$ У случају да

\footnotetext{
${ }^{14}$ Из истог разлога се дају друге две тужбе: exercitoia и insistoria. Actio exercitoria ce примењује када је отац или господар поставио сина или роба за заповедника брода и неко са њим закључи посао који има везе с обављањем дужности на коју је постављен. Како се, наиме, у оваквом случају сматра да је посао закључен по вољи оца или господара, потпуно је правично да се да тужба против њега на целокупан износ дуга - чак и ако је за заповедника брода постављено лице ван породице, било туђи роб, било слободан човек - може ипак подићи против њега (старешине породице) actio exercitoria.

${ }^{15}$ D.14.1.1.1. (Ulp. 28 aded): Под капетаном брода подразумевамо онога на кога је пренета брига о целом броду. ...,„Капетан је морао бити не само особа у коју је exercitor имао највиши ступањ поверења, него и врло образована особа. Заповједник брода одређивао је курс брода, због чега је морао располагати поморским знањима и вјештинама; често је од његове способности овисио спас брода, терета и путника за вријеме олује или гусарског напада. Осим тога, да би држао посаду под контролом, морао је бити угледна и ауторитарна особа."

16 У романистичкој науци је врло спорна одговорност бродара утемељена на овој тужби. Наиме, сукоб постоји око тога шта заправо чини темељ ове одговорности; да ли је то зачетак заступништва или ову врсту одговорности треба
} 
је бродар (exercitor) био позван на одговорност, његова одговорност била је in solidum (за цео износ), што се оправдавало чињеницом да је темељ ове одговорности била његова voluntas, која је управо највише долазила до изражаја приликом именовања одређеног лица за капетана брода. Наиме, пошло се од основног принципа да је дужност сваког pater familias- $a$, па и код именовања капетана брода, да брине и пази кога под свој кров прима и коме поверава вршење својих послова. У случају непоштовања овог правила, било намерно или из разлога небрижљивости, pater familias био је дужан да надокнади штету in solidum или да преда делинквента оштећеном у тапсіріuт како би својим радом надокнадио губитак у имовини тужиоца (Šarac, 2008: 90).

Gai, Inst. 4.70: IN PRIMIS ITAQUE SI IUSSU PATRIS DOMINIVE NEGOTIUM GESTUM ERIT, IN SOLIDUM PRAETOR ACTIONEM IN PATREM DOMINUMVE COMPRAVIT; ET RECTE, QUIA QUI ITA NEGOTIUM GERIT MAGIS PATRIS DOMINIVE QUAM FILI SERVIVE FIDEM SEQUITUR. (Romac, 1973: 357) $)^{17}$

Зато, његова одговорност није била omnis culpa, већ је у неким случајевима одговарао и за стручост чланова своје посаде и својих помоћника, а у неким случајевима и за custodia. Овај вид одговорности је додатно отежавао положај exercitor-a, јер је његова одговорност била и иначе већ пооштрена помоћу actiones adiectitiae qualitatis, а у класичном периоду добила је обележје објективне одговорности (culpa in custodiendo). Увођење овог вида одговорности било је неопходно, јер је она представљала основ на коме се заснивао однос поверења између даваоца и корисника услуга. Са друге стране, непостојање овог вида одговорности доводило је до општег стања несигурности, па су тако бродари, у једном периоду, били на „лошем гласу”, јер се сматрало да су често организовано деловали са крадљивцима, а све у намери да себи прибаве противправну имовинску добит (Ignjatović, 2018: 127).

Тако, у случају судара бродова, до кога је дошло кривицом чланова посаде или magister navis-а, римско право је стајало на становишту да бродар (exercitor), одговара према начелима одговорности за штету коју почине чланови његове посаде, на роби, стварима и особама на броду, и то на квазиделиктној основи (actio furti et damni adversus nautas), па је зато његова одговорност била процењена, према правилима преторског права, in duplum. То даље значи, да је код судара бродова, у римском праву преовладавало схватање одговорности бродара по принципу кривице (Horvat, 1967: 8).

искључиво посматрати са аспекта voluntas exercitor-a, будући да је она била најбитнија за сам акт preapositio.

${ }^{17} \mathrm{Gai}$, Inst. 4.70: Тако, на првом месту, ако је правни посао закључен по наређењу оца или господара, претор је установио солидарну тужбу против оца или господара, што је и сасвим оправдано, јер онај ко је на тај начин закључио уговор више је водио бригу о очевој намери него о намери сина или роба. 
У ситуацијама када је долазило до бродолома, још од најранијег периода постојала су супротна размишљања о томе да ли у овом случају бродар (exercitor) одговара и за оне ствари које су magister navis или чланови његове посаде задржали за себе, а које су биле нанете на обалу. Према једном схватању, сматрало се да је постојао прастари обичај по коме су становници обале могли након бродолома да задрже ствари које би се нашле на обали, и то путем окупације. Из тога се изводи закључак да су ово право имали онда и чланови посаде, па и сам magister navis, што би у крајњем значило да бродар није одговарао. Међутим, према другом, општеприхваћеном, схватању, сматрало се да у оваквим ситуацијама важи правило задржавања власништва. То је даље значило да, уколико би чланови посаде или magister navis, по преживелом бродолому, задржали ствари за себе (lucrandi animo), они би чинили крађу таквих ствари (Horvat, 1967: 14), ${ }^{18}$ па је у том случају бродар (exercitor) морао да одговара по основу пеналне тужбе actio in factum, или по основу actio furti et damni adversus nautas, па и по основу actio exercitoria. Наиме, дошло се до закључка да је било неопходно да се власници ствари извучених из мора, након бродолома, морају изјаснити да ли је било речи о дерелинквираним стварима. Само након ове изјаве власника, те ствари могле су бити предмет присвајања, и то окупацијом, и само у том случају се бродар (exercitor) могао ослободити одговорности (Ignjatović, 2018: 127).

Са друге стране, сматрало се да ако је неко лице, члан посаде, magister navis користио опасну ситуацију, страх и тескобу која влада приликом бродолома, да је починио грабеж, који је био изједначен са пљачкашким походом (rapina). У том случају, против бродара (exercitora) могла је бити подигнута и пенална тужба, по основу које би он био одговоран за четвороструку вредност робе (Horvat, 1967: 15). Наведена правила важила су и у случају „генералне хаварије”, добровољног избацивања терета са брода у море у опасним ситуацијама.

У случају спасавања и помагања на мору, само једно место у Јустинијановим Дигестама упућује на то да је идеја о помагању била позната и Римљанима. Позивајући се на сенатску одлуку из времена цара Клаудија, било је предвиђено да је требало казнити, и то према Lex Cornelia de sicariis, све оне који би силом спречили да се не помогне броду или људима на броду у опасности (Horvat, 1967: 23). Из овога се може посредно закључити да је помагање било обичајна дужност и да je, уколико би то ускратили чланови посаде или magister navis, који су по налогу бродара (exercitor-a), обављали пловидбени подухват, у том случају бродар (exercitor) могао бити позван на одговорност по основу actio exercitoria.

Дакле, питање бродареве одговорности код actio exercitoria никада није било спорно. Међутим, оно што је изазивало супротна схватања

\footnotetext{
18 У том случају, они су били изједначени са оним лицима која су присвајала ства-
} ри које су некоме случајно испале на путу са натоварених кола. 
још од најранијег периода било је питање да ли код ове тужбе треба говорити о одговорности бродара in solidum или је ипак његову одговорност требало свести на неку разумну меру и одредити је као одговорност de peculio (до висине пекулијума) (Šarac i sar., 2017: 426). Како је у класичном праву акценат код actio exercitoria искључиво био стављен на voluntas бродара, јасно је да је класично право стајало на становишту да је одговорност бродара код послова које су закључивала именована лица била in solidum, и поред присутних мишљења да се ова ситуација може посматрати и као зачетак послова заступања, па да у том случају има места умањењу бродареве одговорности. Дакле, основ бродареве одговорности била је његова voluntas да одређено лице именује за капетана брода, које би по његовом налогу закључивало одређени посао и отуда је његова одговорност била за цео износ и трајна. То је даље значило да је, и након његове смрти, друга уговорна страна могла да тужи бродареве наследнике. Такође, одговорност бродара није престајала ни у случају смрти капетана брода или промене његовог статуса.

Међутим, поједини правни извори, као нпр. четрдесет седма књига Јустинијанових Дигеста, наводе и случајеве када се бродар могао ослободити ове одговорности. Тако се предвиђало да се у случају крађе (furtum) бродар могао да ослободи одговорности у своје име ноксалном предајом роба. Међутим, овде се логично поставља питање зашто у овом случају бродар није одговарао као и у случају када је крађа била почињена од стране неког од чланова посаде, где бродар одговара за цео износ. Зашто је ова одговорност предвиђена само у случају крађе почињене од стране члана посаде, слободног човека? У чему се огледа разлика када се за члана посаде ангажује слободан човек, а у чему када је роб? Зашто се тражи од бродара да је, када ангажује слободног човека, било неопходно да утврди његове квалитете са највећом пажњом, па се из разлога непостојања те пажње изводи његова одговорност за цео износ, а зашто се у случају када је крађу починио роб, приступа као у случају да је бродар био у незнању приликом избора роба, ако је био спреман да га ноксално преда? Са друге стране, у ситуацији када је ангажовао туђег роба, одговарао је као за слободног човека, члана посаде (Ignjatović, 2018: 130).

D.47.5.1.5 (Ulp. 38 ad ed.): SERVI VERO SUI NOMINE EXERCITOR NOXAE DEDENDO SE LIBERAT. CUR ERGO NON EXERCITOR CONDEMNETUR, QUI SERVUM TAM MALUM IN NAVE ADMISIT? ET CUR LIBERI QUIDEM HOMINIS NOMINE TENETUR IN SOLIDUM, SERVI VERO NON TENETUR? NISI FORTE IDCIRCO, QUOD LIBERUM QUIDEM HOMINEM ADHIBENS STATUERE DEBUIT DE EO, QUALIS ESSET, IN VERO SUO IGNOSCENDUM SIT EI QUASI IN DOMESTICO MALO, NOXAE DEDERE PARATUS ST. SI AUTEM ALIENUM ADHIBUIT SERVUM, QUASI IN LIBERO TENEBITUR.

Бродар је могао да се ослободи одговорности и када су крађу починили путници, јер се сматрало да он не бира путнике, нити је пак могао да их одбије на путовању. „На броду се не одговара за радње путника.” 
D.47.5.1.6 (Ulp. 38 ad ed.): CAUPO PRAESTAT FACTUM EORUM, QUI IN EA CAUPONA EIUS CAUPONAE EXERCENDAE CAUSA IBI SUNT, ITEM EORUM, QUI HABITANDI CAUSA IBI SUNT: VAITORUM AUTEM FACTUM NON PRAESTAT. NAMQUE VIATOREM SIBI ELIGERE CAUPO VEL STABULARIUS NON VIDETUR NEC REPELLERE POTEST ITER AGENTES: INHABITATORES VERO PERPETUOS IPSE QUODAMMODO ELEGIT, QUI NON REIECIT, QUORUM FACTUM OPORTET EUM PRAESTARE. IN NAVI QUOQUE VECTORUM FACTUM NON PRAESTATUR.

Одговорности је могао да буде ослобођен и онда када је доказао да је до штете дошло услед дејства vis maior (нпр. када је пртљаг на броду страдао у снажној бури или су га отели разбојници) и у случају када су сами ухватили делинквента (нпр. пирата), а да он није био у њиховој служби.

Горенаведени случајеви довели су до релативизације одговорности бродара, па је тако Лабео сматрао да се одговорност бродара сводила само на оне случајеве када је до штете дошло услед превоза робе морем (осим случајева vism aior) и када је штета била учињена од стране самог бродара или лица које је он запослио у својој служби. Друго, уколико је постојао претходни договор између корисника услуга (путника) и бродара у вези са одређеним ризиком и уколико се корисник услуга сагласио са тим, у том случају је постојала ограничена одговорност бродара или уопште није постојала одговорност ако је постојао претходни договор о искључивању одговорности „чувара”. Овде треба истаћи и да је бродар био одговоран само за штету коју су причинила запослена лица, без разлике да ли су то били слободни људи, ослобођеници или робови, иако је до штете дошло на самом броду. Уколико је пак штета причињена од стране ових лица, али ван брода, бродар се ослобађао одговорности (Ignjatović, 2017: 191).

\section{БРОДАРЕВА ОДГОВОРНОСТ У ПОСТКЛАСИЧНОМ ПЕРИОДУ}

Право посткласичног периода носило је све карактеристике тога доба. То је био период пропадања робовласничког уређења и појаве феудалних елемената. Период домината у историји Рима обележен је општом декаденцијом (Boras, Margetić, 1980: 211), ${ }^{19}$ која је

\footnotetext{
19 Проблем декаденције Римског царства питање је које је стално будило пажњу научне јавности и које се покушавало објаснити на најразличитије начине. Једни аутори су објашњење за ову појаву налазили у политичким разлозима, наводећи да, оптерећени питањима наслеђа царског престола, претенденти на то место су водили дуготрајне и исцрпљујуће међусобне борбе, што је довело до слабљења одбрамбене способности државе и краха пред налетом варварских племена. Други су објашњење за тако нешто налазили у морално-духовном посрнућу римског друштва у периоду домината, истичући пропадање старих римских обичаја и врлина, као и пропадање очинске власти и дугих темељних римских института.
} 
захватила све сфере друштвеног живота. Подела Царства на два дела (западни и источни), различит говорни језик, неуспели покушај управљања Царством (Диоклецијанов састав тетрархје), нов начин опорезивања и лоша финансијска ситуација утицали су како на опадање производних снага тако и на слабљење одбрамбене способности државе, што ће довести до тоталног посрнућа и коначно њене пропасти 476. године (пад Западног римског царства) (Boras i sar., 1980: 210). ${ }^{20}$

Најзначајнија последица, која је задесила Римско царство, услед економског и другог опадања, свакако је била поновно враћање пољопривредној производњи. Све гране привреде које су до тада постојале (занатство, трговина, саобраћај, рударство и др.) престале су да постоје уколико нису биле у функцији пољопривреде (Lot, 1927: 62-64). ${ }^{21}$ То је директно утицало на опадање моћи Царства и на драстично смањење промета и трговине, а са друге стране афирмисало је започет процес натурализације. Општа тенденција била је враћање затвореној кућној производњи, која је у центру збивања имала велепосед, као центар укупних друштвених дешавања. Овакав начин привређивања био је неспојив са робним карактером производње, што је довело до слабљења и тоталног губитка средњих имања, која више нису имала никакве услове за даљи опстанак. Оваквом развоју догађаја одговарало је и слабљење државне власти, која није била у стању да се супротстави све израженијем процесу натурализације. Тенденција пораста велепоседа довела је до појаве колона, самосталних сељака, који су по својој вољи или силом прилика улазили у састав велепоседа, јачајући на тај начин улогу власника поседа. Власник поседа је, по мишљењу Beaudoin, био нека врста iudexprivatus, што је било супротно начелима касног Римског царства. Али, и поред постојећих забрана, он је фигурирао у својој пуној снази, што је било последица слабости државе, на једној страни, и јачања поседа, на другој (Beaudoin, 1889: 71). На тај начин, велепосед је добијао

\footnotetext{
20 „Чини се да је основна грешка домината била у спутавању свих извора богатства империји. Начелна везаност уз занимање, нарочито наследна везаност колона за земљу, увелико је спутала стваралачке снаге становништва, а везаност разних имовинских маса умртвила је велики дио националног богатства... Свака провинција животарила је како је најбоље знала притиснута централном администрацијом и домаћим велепосједницима, а спона међу провинцијама биле су још само управа и војска.”

21 Анархија, која је уследила у периоду домината, била је период насиља, пљачки, несигурности за живот и имовину, па је то довело до тога да су трговина и размена у многим подручјима сасвим замрли.
} 
све више на својој економској самосталности и независности, а окупљао је људе ширег региона (Romac, 1966: 62). ${ }^{22}$

Са друге стране, лоша ситуација у привреди одражавала се и на одбрамбену способност државе. Одржавање војске услед постојања натуралне призводње било је готово немогућа појава. Обезбеђивање војске храном, опремом, одећом и обућом у све несигурнијим приликама у држави, услед учесталих варварских напада, и поновне појаве пирата на мору - постало је крајње отежано (Ignjatović, 2015: 79-80).

Нестабилност новца, стављање свих грана привреде (занатство, трговина, саобраћај, рударство и др.) у службу пољопривреде, несигурност пловидбе на мору - директно је утицало на измену концепта бродареве одговорности. Она више није, као у претходном периоду, своје утемељење тражила у voluntas бродара, већ се сада акценат стављао на сигурност пловидбе и заштиту интереса путника. С тим у вези, да би осигурала своје интересе, друга уговорна страна морала је да се, пре закључења уговора са капетаном брода, информише о границама његових овлашћења, као и о ономе што је било наведено у praepositio. Такође, морала је да се информише и о самој личности exercitor-a, као и о томе да ли ће он у крајњем сносити одговорност за обавезе из послова које су за њега закључила овлашћена лица.

Са друге стране, будући да се капетан (magister navis), јављао у улози друге уговорне стране, exercitor је на основу praepositio преузимао на себе суодговорност. То значи да је, поред exercitor-a, на одговорност био позиван и magister navis, под условом да је био уговорно способан.

Као што се може приметити у посткласичном периоду, са декаденцијом у поморском саобраћају нестаје класична фигура exercitor-a. Чак може са сигурношћу да се закључи да је у овом периоду дошло до оне ситуације коју смо имали на почетку развоја поморске пловидбе, а то је да су власник брода и капетан брода били обједињени у једну личност. Заправо, све више се губио траг ius exercitoria, што се опет може објаснити распадом навигације. Распад навигације, са друге стране, довео је до тога да су морем претежно саобраћали бродови скромног терета, па је из разлога економске исплативости било да се власник брода и руководилац експедиције обједине у исту личност.

С обзиром на чињеницу да је због општих прилика у држави тога доба акценат био стављен на сигурност пловидбе и заштиту интереса путника, а не на voluntas бродара, praepositio је више подсе-

\footnotetext{
22 „Понекад се такво понашање римских великаша тумачи као губитак колективне свести и небрига за интерес Царства као целине, а разлози се за то проналазе у разним утицајима, уз остало, и утицају хришћанства и цркве, промењеног социјалног састава виших слојева друштва, нестанка староримске честитости и сличним разлозима."
} 
ћао на овлашћење за заступање. Вољу изражену у praepositio конкретизовао је magister navis закључивањем одређеног правног посла, што значи да се он управљао примарно својом вољом. Притом, римско право остало је код основног принципа да се обавезује онај који је закључио уговор, што значи да се обавезује и посредник који је уговор закључио. На основу наведеног, може се закључити да, у овом периоду код капетана брода (magister navis) још увек није постојало овлашћење за заступање у правом смислу те речи. Он је закључивао послове у своје име и постајао је уговорни партнер. Закључење уговора, са друге стране, обавезивало је и самог бродара (exercitor-a) јер је капетан на основу његове воље био овлашћен, и то само у оним ситуацијама када капетан није прекорачивао границе овлашћења. То је доводило до тога да је друга уговорна страна морала приликом закључења правних послова да води рачуна како о личним карактеристикама капетана брода тако и о личним карактеристикама и интересима самог бродара (exercitor-a).

\section{ЗАКљУЧАК}

На основу свега горенаведеног, можемо доћи до закључка да је институт бродареве одговорности у римском праву имао свој одређени еволутивни ток. О овом институту римског права почиње да се говори у последњем периоду позне републике, када је дошло до развоја поморског саобраћаја и поморске трговине. Наиме, имајући у виду све друштвено-економске околности у којима се развијала поморска пловидба, одговорност бродара била је утемељена на различитим правним принципима. Тако, у периоду позне републике она је представљала одступање од начела alteri stipulari nemo potest, у класичном периоду била је заснована на искључивој voluntas бродара, која се огледала у именовању капетана брода, док у посткласичном периоду развоја римског права ова врста одговорности била је утемељена на принципима сигурности и заштите интереса путника и робе у поморском превозу, што је разумљиво имајући у виду прилике у друштву овог доба (несигурност пловидбе на мору због поновне појаве пирата).

У периоду позне републике, са развојем поморске трговине и са увођењем traditio, који је омогућавао брз промет, стицањем својине a manu in тапи, дошло је до одређених промена у привредној структури римске државе, које су неминовно наметале потребу за ослобађањем од строгог формализма, до тада присутног у сфери својинских односа. Ослобађању од строге форме погодовало је и увођење actiones adiectitiae qualitatis, које су представљале одступање од начела alteri stipulari nemo potest, у циљу постизања веће ефикасности у правно-економском промету. То је, посматрано са аспекта бро- 
дареве одговорности, довело до ширења обима ове одговорности и на оне случајеве када је до одговорности долазило на основу послова које су по налогу патерфамилијаса закључила лица alieni iuris и робови.

У класичном периоду, с обзиром на све израженији консенсуализам, voluntas бродара постала је темељ његове даље одговорности, и као битан елемент била је у духу utilitas navigantium и necessitas contrahendi. Класични период уједно је био и период у коме се овај вид одговорности развио до највишег степена, али и у коме је дошло до његове релативизације. Тако су, у овом периоду, могла да се чују и она мишљења по којима се бродар могао ослободити одговорности in solidum. Истицало се да се одговорност бродара сводила само на оне случајеве када је до штете дошло услед превоза робе морем (осим случајева vism aior) и када је штета била учињена од стране самог бродара или лица које је он запослио у својој служби. Друго, уколико је постојао претходни договор између корисника услуга (путника) и бродара у вези са одређеним ризиком и уколико се корисник услуга сагласио са тим, у том случају је постојала ограничена одговорност бродара или уопште није постојала одговорност, ако је постојао претходни договор о искључивању одговорности „чувара". Овде треба истаћи и да је бродар био одговоран само за штету коју су причинила запослена лица, без разлике да ли су то били слободни људи, ослобођеници или робови, и ако је до штете дошло на самом броду. Уколико је пак штета причињена од стране поменутих лица, али ван брода, бродар се ослобађао одговорности.

У посткласичном периоду, са декаденцијом у поморском саобраћају, нестала је класична фигура exercitor-a. Чак може са сигурношћу да се констатује да је у овом периоду дошло до оне ситуације коју смо имали на почетку развоја поморске пловидбе, а то је да су власник брода и капетан брода били обједињени у једну личност. Заправо, све више се губио траг ius exercitoria, што се опет може објаснити распадом навигације. Распад навигације, са друге стране, довео је до тога да су морем претежно саобраћали бродови скромног терета, па је из разлога економске исплативости било да се власник брода и руководилац експедиције обједине у исту личност. Са друге стране, због општих прилика у држави посткласичног периода, акценат је био стављен на сигурност пловидбе и заштиту интереса путника, а не на voluntas бродара, док је praepositio више подсећао на овлашћење за заступање. Иако овде није било речи о непосредном заступању, правни послови који су у овом периоду закључивали капетани брода са другим уговорним странама, а по налогу власника брода, увеликом су приближили ове радње институту заступања. 


\section{ЛИТЕРАТУРА}

Beaudoin, E. (1889). Les grands domains dans l'Empire Romain, - nouvelle revue historique de droit francais et etranger. [Great domains in the Roman Empire a new historical overview of French and foreign law], Paris

Boras, M. \& Margetić, L. (1980). Rimsko pravo [Roman Law], Zagreb. Pravni fakultet Sveučilišta

Bujuklić, Ž. (2013). Rimsko privatno pravo [Roman Private Law], Beograd. Pravni fakultet

Gai Institutions (2009). (prevod: Stanojević,O.), Beograd. Zavod za udžbenike

Grupče, A. (1962). Odgovornost za štetite storeni od maloletni lica [Liability for damage caused by minors], Godišnik na Pravniot fakultet vo Skopje.

Horvat, M. (1967). Iz historije sudara, brodoloma, spasavanja i pomaganja [From the history of crashes, shipwrecks, rescuing and aiding], Poseban otisak iz Zbornika za pomorsko pravo, Tom 6, Zagreb.

Ignjatović, M. (2017). Actio furti et damni adversus nautas kao oblik osiguranja putnika na brodu, [Actio furti et damni adversus nautasas a form of warranty for passengers on the ship] Zbornik radova sa međunarodne naučne konferencije "Suvremeni izazovi pomorske plovidbe”. Split. Pravni fakultet Sveučilišta. str. 185 - 197.

Ignjatović, M. (2016). Da mihi facto, dabo tibi ius - stvaranje, kreiranje, tumačenje i primena prava u starom Rimu (Da mihi facto, dabo tibi ius- [The formation, creation, interpretation and application of law in ancient Rome], Ius Romanum, Balkan Association of Roman law and Roman legal tradition, str. 1-14.

Ignjatović, M. (2015). Emphyteusis u rimskom pravu [Emphyteusis in Roman Law], Zbornik na trudovi, Vtora medjunarodna konferencija „Opštestveni promeni vo globalniot svet“, Štip. Praven fakultet. str. $77-84$.

Ignjatović, M. (2018). Theft on board of a vessel as a special form of theft in the Roman law, Zbornik radova sa međunarodne naučne konferencije "Suvremeni izazovi pomorske plovidbe". Split. Pravni fakultet Sveučilišta. str. 119-135.

Ignjatović, M. (2002). Zaštita ljudskih i manjinskih prava u doba rimske republike [Protection of human and minority rights in the Roman Republic], Zbornik radova Pravnog fakulteta Univerziteta u Nišu, tematski broj: ,Zaštita ljudskih i manjinskih prava u evropskom pravnom prostoru", Niš. Pravni fakultet. str. 321-334.

Lot, F . (1927). La fin du monde antique et le debut du Moyen Age, Paris

Paulo, J. (1989). Sententiae ad filium, Libr. VI. De exercitoribvs et institoribvs, priredio i preveo: Romac, A., Zagreb. Latina et Graeca

Pezelj, V. (2017). Patronus navis u dalmatiskom statutarnom pravu [Patronus navis in Dalmatian statutary law], Zbornik radova sa međunarodne naučne konferencije „Suvremeni izazovi pomorske plovidbe”. Split. Pravni fakultet Sveučilišta. str. $311-335$.

Romac, A. (1973). Izvori rimskog prava [Sources of the Roman Law] (latinski tekstovi s prevodom), Zagreb. Pravna biblioteka

Romac, A. (1994). Justinijan Institucije [Iustinian Institutions], Zagreb. Latina et Graeca

Romac, A. (1966). Rimska privreda i proces njene naturalizacije [Roman economy and the process of its naturalization], Anali Pravnog fakulteta u Beogradu, Beograd. str. $52-65$.

Šarac, M. (2008). Actio exercitoria, Zastupanje u pravnim poslovima u rimskom pravu, [Representation in legal affairs in Roman law], Split. Pravni fakultet Sveučilišta

Šarac, M. (2011). Mandatum u rimskom pravu [Mandatum in Roman Law], Split. Pravni fakultet Sveučilišta 
Šarac, M \& Miletić, T. (2017). Odgovornost brodara u rimskom pravu [The shipper's liability in Roman law], Zbornik radova sa međunarodne naučne konferencije "Suvremeni izazovi pomorske plovidbe". Split. Pravni fakultet Sveučilišta. str. 421-433.

Stojčević, D. (1947). Rimsko pravo I deo: društveno-ekonomski uslovi pod kojima se razvijalo rimsko pravo, statusno, porodično, stvarno, nasledno i krivično [Roman law Part I: social and economic conditions under which Roman status, family, property, inheritance and criminal law developed], Beleške po predavanjima održanim u školskoj 1945/46, Beograd. Pravni fakultet.

\title{
EVOLUTIONAL DEVELOPMENT OF THE SHIPPER'S LIABILITY IN ROMAN LAW
}

\author{
Marija Ignjatović \\ University of Niš, Faculty of Law, Niš, Serbia
}

\section{Summary}

The first time shipman's accountability has ever been mentioned was with the development of naval trade. The evolutionary course of the institute of shipman's accountability involves its beginning at the final period of the late republic when the development of naval transport and naval trade was on the rise. In the period of the late republic, it represented an exception to the rule of alteri stipularui nemo protest, which led to the augmentation of its scope - both in those cases when the accountability was a result of the business ordered by paterfamilias, which were concluded between the parties of alieni luris and slaves. In the classical period, it was based on the exclusive shipman's voluntas, and it was in the spirit of utilitas navigantium and necessitas contrahendi. In the postclassical period, this kind of accountability was based on the principles of security and the protection of interests of passengers and merchandise in naval transport, which was, first of all, caused by the decay of the navigation system.

Due to the decay of navigation, ius expectoria trace was being lost. Thus, from the reasons of economic affordability, the ship owner and the expedition leader were embodied in one personality, which additionally affected the change of concept of the shipman's accountability. 